\title{
Moss Bag Preparation: A Low-Cost Technique in Monitoring Airborne Particulate and Toxic Elements
}

\author{
Francis Olawale Abulude ${ }^{1, *}$ and Jamok Jacob Elisha ${ }^{2}$ \\ ${ }^{1}$ Science and Education Development Institute, Ondo State, Nigeria; ${ }^{2}$ Centre for Biotechnology \\ Research and Training, Ahmadu Bello University Zaria, \\ Kaduna State, Nigeria; jjelisha57@yahoo.com \\ *Correspondence: waleabul@yahoo.com or samuel.fagbayide@federalpolyilaro.edu.ng
}

\begin{abstract}
Air pollution has created a lot of problems in the developed and developing countries. To avoid or reduce these problems, constant monitoring of the air should be ensured. The conventional techniques is costly because it requires a lot of money and time consuming. Biomonitoring has been the alternative method. Moss, lichens and plants are biomonitors available to entrap air pollutants. The aim of this paper is to discuss one of the ways of monitoring air pollution - Moss bag technique. To do this, types, choice, preparation, handling of bags after preparation of moss were discussed. From the literatures consulted, it was discovered that there were differences in the techniques used by the researchers. In all, the use of mosses with emphasis on the employment of moss bag have proved to be a powerful tool in airborne particulate and toxic elements. To conclude, developing countries should focus more on this technique because it will reduce cost of air monitoring.
\end{abstract}

Keywords: air pollution; mosses; low-cost; equipment; time-consuming

\section{INTRODUCTION}

Anthropogenic and non-anthropogenic activities have increased throughout the world. The consequence is air pollution. Air pollution has created a lot of problems which have affected living and non-living things. According to WHO [1], over 2.4 million premature deaths are linked to urban air pollution problems. Traffic-related air pollutants are associated with toxic elements are on the increase, these are found at elevated concentrations on the roads (paved and unpaved). To avoid air pollution problem or to reduce it, constant monitoring is important. These will provide the values indicating whether the environment is polluted or not. The results obtained will inform the right steps to undertake.

Most air pollution analysis requires equipment which is costly, not readily available and timeconsuming. According to Gatziolis et al. [2], in Portland, Oregon, US the cost of providing one permanent air toxic monitor is $\$ 40,000$ annually to metals. Further, it was observed that one instrument is not enough for the task of monitoring at a neighborhood level. In developing countries there is bound to be a problem due to the high cost involved. Biomonitoring of air pollution has been on since 40 years ago [3]. Bioindicators are used to check changes in the environment, monitor for the presence of pollution and its effect on the ecosystem [4]. Many types of bioindicators are useful and suitable for wide range of applications. According to Vuković et al. [5], biomonitoring depicts a simple and cost-effective alternative means to regulatory 
monitoring of air quality. Moss, lichens and plants are biomonitors available to entrap air pollutants. Moss lack developed root systems and thus obtain its nutrients from the air and other sources. It has a high surface/volume ratio and high cation exchange capacity which increases its adsorbent efficiency. Moss also lacks a variability in morphology throughout the growing season, also it has no cuticle, accumulates large amounts of trace elements [6].

'Moss bag technique' was introduced by Goodman and Roberts [7] since then it has been used over the last several decades as a useful technique of active moss biomonitoring of pollutants such as heavy metals, non-metals and PAHs. This technique has been useful for conducting a detailed survey of the polluted urban areas, where native mosses are usually absent because of predominantly paved and landscaped surfaces [8]. In contrast to instrumental measurements, moss bags do not require power supply and maintenance. Thus, the moss bag technique could be applied to obtain a satisfactory spatial resolution of monitoring sampling sites, and consequently a detailed database. Another important difference between the moss bag technique and instrumental measurements is sampling time [9]. Instrumental measurements are usually carried out within short time periods, providing a daily concentration of pollutants, whereas moss bags act as a longterm integrator of air pollutants providing average concentration. Long-term sampling is a prerequisite for the assessment of cumulative exposure to a certain pollutant that has a hazardous effect on human health.

Most literature have grouped biomonitoring into two parts namely passive and active biomonitoring. Passive biomonitoring uses mosses grown in natural in an area, while active biomonitoring is the use of transported moss from another location. According to Ares et al. [3], native mosses used for passive biomonitoring are used for studies in large areas especially regional and national studies. Active biomonitoring is useful for studies in smaller areas.

The aim of this paper was to review method of biomonitoring using moss bag technique.

\section{METHODOLOGY}

\section{Types of Moss}

Over 22,000 varieties of moss are in existence worldwide [10]. There are various ways in a choice of moss this can be done by deciding on what to do with it. Many are found in the forest and can be cultivated in homes.

Few examples of the moss given by Baessler [10]. include:

i. $\quad$ Sheet moss is grown anywhere most especially at foot traffic paths.

ii. Cushion moss grows to form a ball-like form. It changes colour from dry form to wet.

iii. Ceratodon moss grows between stones.

iv. Fern moss compared to other mosses is a fast growing organism. It is a good and strong grass.

v. Rock moss is good for planting in flower gardens. It slings to stones.

vi. Haircap moss resembles a tiny forest and provides a good height. 
Others specified by Moss Catalog [11] are: Tree apron moss, moss rocks, moss roofs and wall, reindeer moss, moss for sunny areas, moss for terrariums, moss grab bag, moss starter and moss mat.

\section{Choice of Moss}

There are many species of moss throughout the universe. The reason for the choice of species depends largely on the availability and abundance of the study locations, which has enabled the use of native and transplanted moss in some studies [3]. The different mosses available, have been employed in comparative studies due to the abundance within the vicinity of the study area. The following criteria are used for the sampling of moss for various researches using the bag technique.

i. preference for widely distributed and pleurocarpous mosses,

ii. the selected samples should have some structural and physicochemical characteristics that will enable efficient uptake of contaminants from the atmosphere,

iii. the selected ones should be species of the most commonly employed researches and which have existing information readily available.

iv. the capacity of the different species of moss to accumulate contaminants.

The capacity of the species to capture the contaminants have been given by Giordano et al.

[6]. These have been corroborated by another author elsewhere [12 - 14].

\section{SPECIES SELECTION}

To date many different species have been used in researches on air pollution. The different species employed affect the results. According to Ares et al. [3], over 55\% of the different species have been used on one occasion or the other. According to the report provided by the team of researchers, reasons for the selection was based on availability and abundance, availability throughout the seasons (harmattan, rain, spring, autumn) and tolerance to the pollutants [15].

Table 1 depicts few examples of mosses selected due to the reasons highlighted above.

\begin{tabular}{llc}
\hline \multicolumn{1}{c}{ Moss Samples } & Country & References \\
\hline 1. Sphagnum capillifolium & Italy & {$[16]$} \\
2. Hypernum cupressiforme & Italy & {$[16]$.} \\
3. Leptodon smithii & Italy & {$[17]$} \\
4. Fabronia ciliaris & Mexico & {$[18]$} \\
5. Sphagnum girgensohnii & Belgrade & {$[19]$} \\
6. Sphagnum girgensohnii & Belgrade & {$[20]$} \\
7. Isothecium myosuroides & Ireland & {$[21]$} \\
8. Isothecium myosuroides & Ireland & {$[21]$} \\
9. Hypernum cupressiforme & Belgrade & {$[5]$} \\
10. H. cupressiforme & Italy & {$[22]$} \\
11. Pleurozium schreberi & Funlundi & {$[23]$} \\
\hline
\end{tabular}

Apart from the basic criteria previously listed, other reasons of sampling could be:

i. Mosses should have a limited biological variation

ii. Sampling and sample preparation should be simple and fast

iii. Mosses should have low background concentrations of elements.

iv. Uptake of elements should be independent of local conditions 
v. Information of the moss should be widely available

\section{Moss bag preparation Selection of sample}

Before a moss bag can be prepared for analysis. There is the need to select appropriate moss for the preparation. The old or young shoot of the moss should be selected. It is on record that older parts of the stem contain different amounts of some elements than younger tissues [24]. Different substrates and exposure to the atmosphere could be considered too. The reason is that elemental deposition of moss on soil and rock dust is quite different from ones grown on tree trunks [25]. Other considerations for selection could be the use of the whole shoot, or green part of the shoot or the use of apical portions of similar size. It is very important to consider samples that are homogeneous.

\section{Area of Study}

Area of sampling and study is an important point to be noted during the research design. The hot spots should be accurately mapped out before embarking on the study. It is important to note the period in which to sample this could be needed to capture the different seasons (rain, harmattan, winter, summer, spring and autumn). Traffic effects could be studied too because traffic is considered to be the major source of pollution during summer season [5] industrial activities, subUrban, Urban, Rural and green zones could be considered too. Other areas can be identified apart from the earlier suggestions. It is paramount that mapping of the hot spots should be determined before setting out on the proposed study.

During the experimental periods, meteorological parameters (air temperature rainfall, wind speed and direction, pressure, the sunshine, humidity and others should be considered. Meteorological equipment can be stationed in the sampling spots.

Again, the use of GPS in an important factor. This will assist in determining the location of the spot. The longitude and latitude of the area are determined.

Also, the timing of the research work should be considered. The length of time could be daily, week, two weeks, monthly and a year or many years.

\section{Sample Treatment (Exposure and Post-Exposure)}

Treatment of sample is an important task for the sample to be adjunct ready for use. The sample can be treated or not treated prior to exposure. For the moss to be live or dead it depends on the pre-exposure treatment and the objective of the study. The purpose of treatment is to get a transplant with similar and well-defined initial features like morphology, well characterized initial contents of contaminants, comparable physiological status $[3,6]$.

\section{Cleaning of Sample}

It is important that moss should be cleaned before preparation of the moss bag. Different methods are employed for the cleaning. Any of the followings could be used for cleaning.

\section{Water Washing}

The objectives of washing in water are: 
i. To activate (partially) the tissues through the removal of some elements bound to cation exchange sites of the moss cell wall and membrane.

ii. To clean the particles and plant remains.

The results of the washing steps are determined by the number of washing, duration, type of water used, the relation between the weight of the moss and volume of water used [26, 27]. Information about this method of washing was reported by Giordano et al. [6]; Zarazua - Ortega et al. [18] and Vukovic et al. [5].

\section{Drying of Moss Samples}

Drying is meant to reduce the water or moisture content in a sample. Drying of moss is not an exceptional. Drying can be effected using many methods which include:

\section{Oven drying}

This is a method consisting of maintaining the material in an oven at a specific temperature usually using less than $100^{\circ} \mathrm{C}$ for about 24 hours. Consideration on temperature should be made if a live moss is going to be employed for the research work because at very high temperature it may denature the moss or some metals may be volatilized. Giordano et al. [6] gave some reasons why oven drying is better than acid washing or other methods. The reasons include:

i. Eco-friendly (ii) morphology and leaflet arrangement of moss unaltered, while the disadvantage is found on the shoots which become brittle and leaf fragments tends to fall off the stem.

Drying mosses using mesh bags has reduced the loss of materials. The disadvantage is that drying does not release metals bound to cation exchange sites. Wilkins and Aherne [21] oven dried their samples at $60^{\circ} \mathrm{C}$ for 70 hours, while Ares et al. [27] dried their samples at $75^{\circ} \mathrm{C}$

\section{Air drying}

This is a method whereby mosses are relieved of the excess water or acid that are left on them after washing to $40^{\circ} \mathrm{C}$. The temperature should not cause the death of moss and dried to a constant weight. Suoranta et al. [23]; Vukovic et al. [5]; Vukovic et al. [28], Vukovic et al. [20] have reported on this technique of drying.

\section{Freeze drying}

Zarazua - Ortega et al. [18] used the freeze-drying method in their sample preparation. The sample was carefully washed, freeze-dried, ground, sifted and homogenized. The resultant moss sample was digested for subsequent analyses.

\section{Homogeneous Sample}

In all the studies reviewed, the final step in the production of moss sample was homogenizing the dried mosses. In summary, it was observed that the followings were used:

i. Hand mixing

ii Centrifugal mill

iii Mortar and pestle

iv Mixer mill 
V Blender

\section{Preparation of transplants}

Moss transplant is a method used in moss bag preparation. This involves the placing of moss in some support like a mesh net bag or mats. In the case of the use of supports, mat, the moss from an unpolluted area is embedded into a mat form and this is transplanted into contaminated area for as long as the research will be concluded. This method is similar to that used within native moss monitoring. It is meant to evaluate the degree of adaptation of nature moss to the contamination in a particular area [8].

\section{Unwashed}

De Nicola et al. [17], Vikovic et al. [28], Wilkins and Aherne [21] and Suoranta et al. [23] conducted their research work without washing their samples. All they did was to make sure the samples were devoid of impurities (foreign matters). De Nicola et al. [17], removed dead or extraneous matters under a binocular microscope. In the study carried out by Giordano et al. [6] it was reported that differences in metal values within the moss samples exposed after washing with water and acid did not differ significantly.

\section{Acid washing.}

Also known as activation. This treatment is about washing the selected mosses in an acid medium. The aim of this is to leach the metal wins from the cell walls $[6,25]$ and disrupting biological membranes [29]. This regenerates the cation exchange sites found in the cell wall, with the aim of increasing the bioconcentration capacity of the exposed moss. Giordano et al. [6] recommended acid washing $\left(1 \mathrm{~N} \mathrm{HNO}_{3}\right.$, ratio $1: 2 \mathrm{v} / \mathrm{v}$. In the review work of Ares et al. [3] it was noted that various concentrations were used $0.0025 \mathrm{M}$ and $1 \mathrm{M}$ were used by about $54 \%$ authors, while about $80 \%$ authors recommended 0.01 and $0.5 \mathrm{M} \mathrm{HCl}$.

Mosses were rinsed thrice with double distilled water (10L of water was used per $100 \mathrm{~g}$ of moss and shaken for 10mins).

\section{Devitalizing Treatment}

Attentions have been given to this treatment since decades [26, 30, 31]. The use of this treatment depends on the type of research which may be to bio-monitor atmospheric contaminant or to study the effects of contamination on moss. The use of live moss is ideal for the first aim (biomonitoring) while dead moss is good for the effect of contamination on moss. However, the use of dead samples has some advantages over the use of live samples. For example, at all times (i) moss metabolism cannot have any effect on the results or outcome (ii) the results or outcome will be less variable. The use of dead moss is suitable in urban and industrial areas. The use of live moss is an active monitoring of air pollutants which provide spatial and temporal information on sources and deposition patterns of atmospheric contaminants [32].

The transplanted moss can be placed within a frame constructed with wood [33] or plastic [34] or without the use of frame.

The transplanting of moss in a net bag depends on the size of the bag, size and composition of a mesh net, auto irrigation systems [3]. Each of the characterization would be discussed below: 


\section{(i) Mesh net material}

Various materials have been used from the literatures reviewed. It could be summarized that net materials could be (i) nylon (ii) Polythene (iii) polypropylene (iv) glass fibre (v) mosquito nets (vi) cotton (vii) metal and (viii) non-plastics from the findings, it was observed that plastics and glass fibre were better because non-plastics may interfere with the uptake process.

\section{(ii) Mesh size}

Selection of the sizes of the mesh to be used in important. The loss of materials during research should be prevented. Also the thickness of the mesh should be considered too. If the thickness is much, there is the likelihood that the capture of the contaminants by moss may be high which may intercept and retain particulate materials [35]. The recommended sizes should be between $1-150 \mathrm{~mm}^{2}$.

\section{(iii) Bag Shape}

There are three categories of shapes of moss bags. They are cylindrical, spherical and square or rectangular shapes (three-dimensional) the spherical and cylindrical shapes allow uniform collection efficiency from all directions. It also allows sample collection by gravitational sedimentation in flat or rectangular shape (two-dimensional), explosive of the moss is uniform to the atmosphere. If compartments are made in the bag, the capture of elements in the atmosphere is improved.

\section{Quantity of moss in bag}

When considering the use of moss bag technique in biomonitoring, it is paramount to take the followings into consideration (i) In the experimental design sufficient moss materials should be readily available in the natural environment (ii) enough material should be available and (iii) loss of material during the exposure. It is important that sufficient (large amount) moss material should use to avoid a shortage of sample during experimentation. (i.e handling and exposure). The surface area $\left(\mathrm{M}^{2} \mathrm{~kg}^{-1}\right)$ of the bag and moss could determine the better efficiency of metal accumulation. The recommended amount of moss in each bag should be between 100 and $200 \mathrm{mg}$.

\section{Size of bags}

According to Ares et al. [3], the size of the bag determines the ratio between the weight of the moss and the surface area of the bag. The ratio determines the efficiency by which the transplants attracts contaminants from the atmosphere. In the studies carried out with the use of moss bag technique, the calculated ratio $\left(\mathrm{mg} \mathrm{cm}^{-2}\right)$ was between $<40$ to $>110$. It was recommended that moss should be loosely packed in thin layers [40]. When moss is loosely packed, it reduces overlapping compression of the moss and even exposure of the moss to the contaminants. Temple et al. [35] found that bag withy weight/surface area ratio of $30 \mathrm{mg} \mathrm{cm}^{-2}$ were ideal for the maximum uptake.

\section{Handling of bags after preparation}

This is an important area of consideration. To prevent spoilage by bacterial activity, loss of material and contamination of the bag. They should be stored at low temperatures or sealed in plastic bags prior to exposure in the sampling areas. 


\section{Exposure}

The concentrations of contaminants in the moss are affected by the type of support, height and duration of the exposure, shading and cover number of bags exposed and different systems of irrigation.

Live mosses have been used for the moss bag technique most mosses used for the exposure are live. There are two techniques used in overcoming the death of the moss during exposure periods. Auto irrigation and spraying of the mosses are employed. In auto irrigation system, mosses are placed on capullaing mat attached to a container (Plastic) filled with water is meant to keep the moss bag wet. According to Clough [36], wet moss bags have a higher speed of deposition of particles than on dry moss bags.

Spraying of the moss bags with distilled water is another method of the irrigation system. This can be carried out once or twice a week $[37,38])$.

An alternative method to using irrigated system is non-irrigated. The problem is that they dry out fast. The efficiency in retaining metals depends on air humidity, precipitation and wind intensity. The velocity of deposition may be higher in dry moss bags than in wet bags, the reason is that in dry moss bags the metal deposition velocity in higher due to the large surface area [40].

Shading net (shading system) can be used during exposure of the moss bags or mat shading net is used to cover the bags order to reduce environmental and hydric stress from sunlight and the wind. Prevention of stress will assist in clearer identification of relationships between the concentrations of certain contaminants in moss tissues and their effect on different physiological variables.

Like the use of shading system, shelters or covered (shelter systems) sites (below balcony) are employed (i) to prevent exposure of the moss bags to wet deposition and or loss by leaching of some of the retained contaminants (ii) cover prevents the largest particles reaching the moss and may alter the dynamics of particle deposition. (iii) it will alter the form and intensity with which the wind affects the moss samples. This finally, influence bio-concentration of the contaminants. Apart from the below balconies used as cover, other includes PVC sheets, pots, inverted funnels [39].

\section{Positioning height and duration of exposure of moss bags}

The positioning of moss bag is important in moss bag sampling technique. The positioning of moss flat or spherical bags must be considered. The reason for this consideration is that positioning affects the uptake of contaminants. The positions of bags must be considered in relation to ground (Horizontal or vertical) and the focal point of contamination. Horizontal positioning of bags increases the capture of contaminants by gravitational sedimentation and wet deposition [7] while flat bags in vertical position captures contaminants present in the air with low sedimentation rates. The orientation of bags relative to the source of contamination should be taken into consideration whenever transplants are used to monitor isolated focal points of contamination.

Interference of the moss bag should be avoided from obstacles like buildings, vegetation and others. 
In the preparation of the moss bags, the followings should be considered (Fig 1):

(i) Supports - plastic tubes, glass fiber poles, steeve

(ii) Materials used - Inert materials that cannot be contaminated

(iii) Structures for hanging - trees, leaning posts

(iv) Moss bags/ mats - nylon fiber

(v) Site/Location - Rooftops, vegetation

(vi) Arrangement of bags - No overlapping, each bag should face cardinal direction

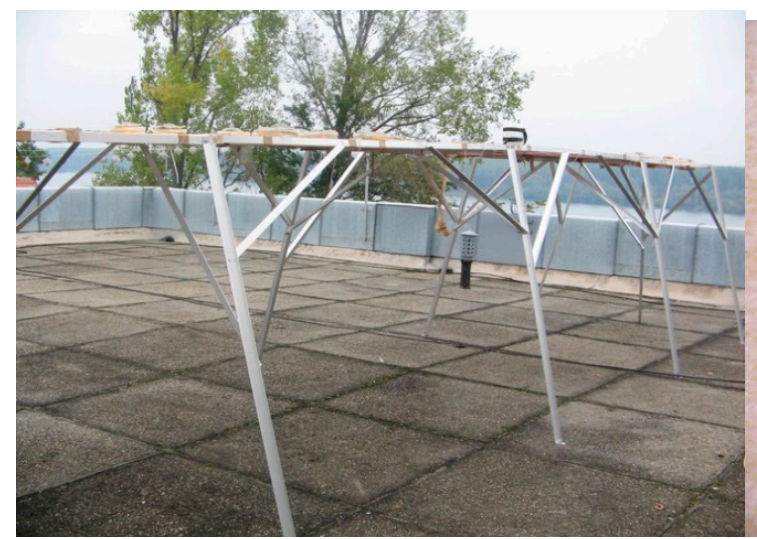

(i)

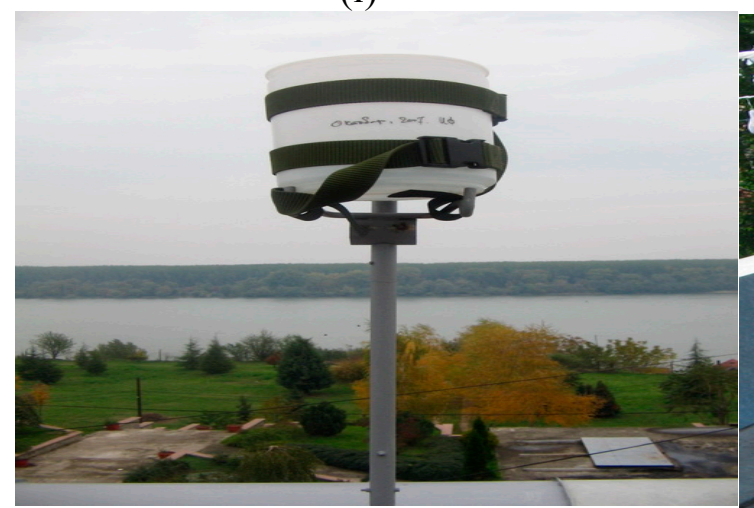

(iii)

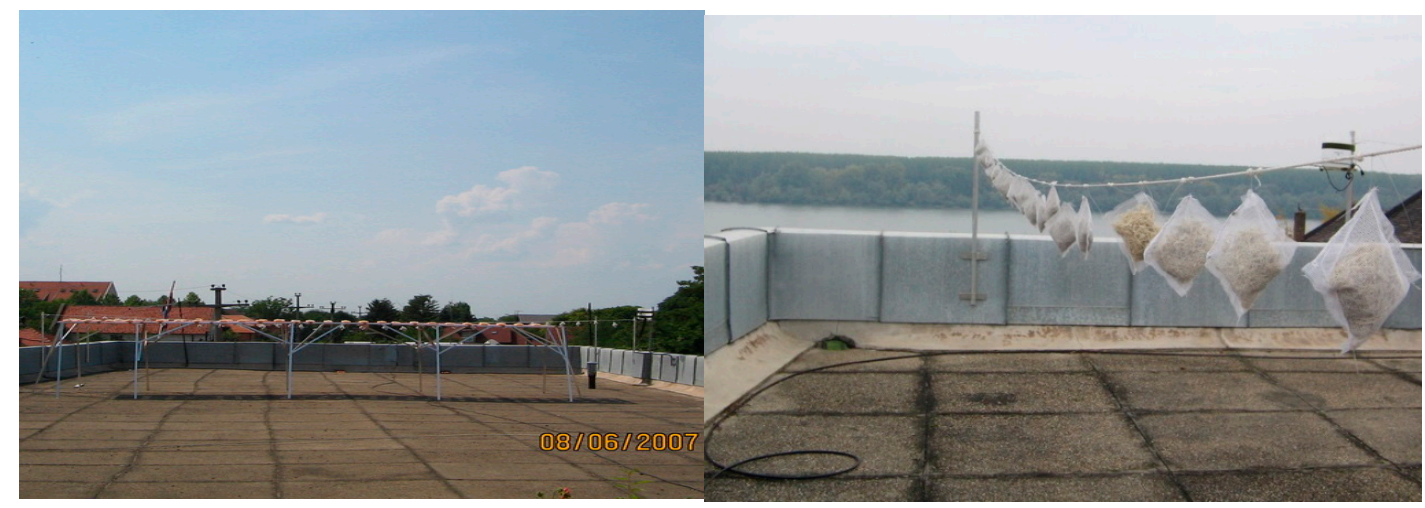

(v)

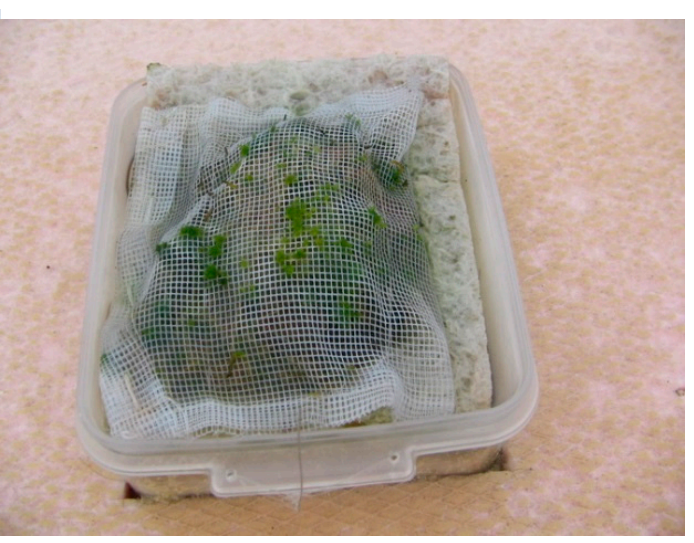

(ii)

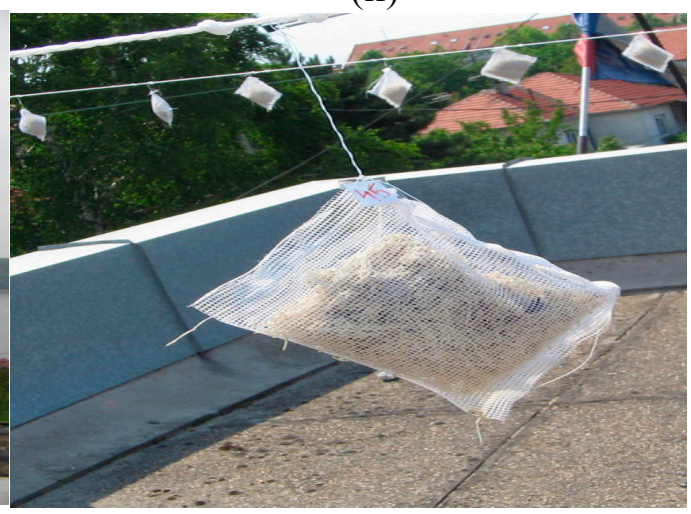

(iv)

(vi)

Fig 1: Considerations in moss bags preparation 
The height of exposure may not be the same there will always be variability depending on the researchers. However, the ground level to $30 \mathrm{~m}$ high has been recommended and used. It was noted that the difference in height affect the results obtained at different locations because airflow and turbulence vary with height above the ground $[25,40]$.

\section{Note}

Low height $(4 \mathrm{~m})$

Height

High height (12-20m)

\section{Emissions}

Related to traffic and suspended dust from roads Related from long-distance transport and marine origin.

In considering the height of exposure, the objective of the study, practical aspects (availability of support to hang the bag and to prevent loss through vandalism) should be paramount.

Duration of exposure also varies. The duration ranges from 1 week to 6 months. The criteria for the duration are:

(i) Detectable accumulated concentrations

(ii) Reliable values

(iii) An exposure period within the limits of practical considerations.

The number of replicates bags and level of error will determine the number of moss bags needed for the research work. The level of error can be calculated, between 5 and $20 \%$ is recommended. For example in some cases, if the number of moss bags required is many, there should be extra bags exposure because of a large difference.

\section{CONCLUSION}

Mosses are a cheap and useful tool for estimating particulate matter and toxic elements in the air. The moss bag technique is simple and cost effective. The moss network provides a useful tool for validating the performance of atmospheric. There is the need to select appropriate moss for the preparation. It is recommended that developing countries should harness the advantages of using the technique.

\section{REFERENCES}

[1]. World Health Organization (2014). Burden of Disease from Household Air Pollution for 2012. World Health Organization, Geneva, Switzerland, p. 17.

[2]. Gatziolis, D., Jovan, S., Donovan, G., Amacher, M., and Monleon, V. (2016). Elemental atmospheric pollution assessment via moss-based measurements in Portland, Oregon. Gen. Tech. Rep. PNW-GTR-938. Portland, OR: U.S. Department of Agriculture, Forest Service, Pacific Northwest Research Station. 55p. 
[3]. Ares, A., Aboal, J. R., Carballeira, A., Giordano, S., Adamo, P., and Fernández, J. A. (2012). Moss bag biomonitoring: A methodological review. Science of the Total Environment 432, $143-$ 158.

[4]. Ejigu, E., Balkrishinan, M. and Bekele, A (2014). Bioindicators for Environmental Monitoring: A Review. Conference: The Second Annual Science Conference of Science College at Bahir Dar University, Ethiopia, At Ethiopia, Volume: 2.

[5]. Vuković, G., Urošević, M. A., Škrivanj, S., Milićević, T., Dimitrijević, D., Tomašević, M., and Popović, A. (2016). Moss bag biomonitoring of airborne toxic element decrease on a small scale: A street study in Belgrade, Serbia. Science of the Total Environment 542, 394-403.

[6]. Giordano, S., Adamo, P., Sorbo, S., and Vingiani, S. (2005). Atmospheric trace metal pollution in the Naples urban area based on results from moss and lichen bags. Environmental Pollution 136 (2005) 431-442.

[7]. Goodman, T.G., Roberts, T.M., (1971). Plants and soils as indicators of metals in the air. Nature, 231, 287-292.

[8]. Kosior, G., Ciężka, M., Górka,M., Samecka-Cymerman, A., Kolon, K., Kempers, A.J., Jędrysek, M.-O., (2015). $\delta 34 \mathrm{~S}$ values and S concentrations in native and transplanted Pleurozium schreberi in a heavily industrialized area. Ecotoxicol. Environ. Saf. 118, 112-117.

[9]. Calabrese, S., D'Alessandro,W., Bellomo, S., Brusca, L., Martin, R.S., Saiano, F., Parello, F., (2015). Characterization of the Etna volcanic emissions through an active biomonitoring technique (moss-bags): part 1 - major and trace element composition. Chemosphere 119, 1447-1455.

[10]. Baessler, L. (2016). Gardening Know How: Garden Moss Types: Varieties Of Moss For Gardens

http://www.gardeningknowhow.com/ornamental/foliage/moss/moss-types-forgardens.htm.

[11]. Moss Catalog (2016). Moss Acres LLC. http://www.mossacres.com/photo_gallery.asp

[12]. Marinova, S., Yurukova, L., Frontasyeva, M. V., Steinnes, E., Strelkova, L. P., Marinov, A., and Karadzhinova, A. G. (2010). Air Pollution Studies in Bulgaria Using the Moss Biomonitoring Technique. Ecological Chemistry and Engineering S. 17 (1), 37-52.

[13]. Aslam, M., Verma, D. K., Dhakerya, R., Rais, S., Alam, M., and Ansari, F. A. (2012). Bioindicator: A Comparative Study on Uptake and Accumulation of Heavy Metals in Some Plant's Leaves of M.G. Road, Agra City, India. Research Journal of Environmental and Earth Sciences. 4 (12): 1060-1070.

[14]. Vuković, G., Aničić Urošević, M., Razumenić, I., Goryainova, Z., Frontasyeva, M., Tomašević, M., Popović, A., (2013). Active moss biomonitoring of small-scale spatial distribution of airborne major and trace elements in the Belgrade urban area. Environ. Pollut. Res. 20, 54615470 . 
[15]. Chakraborthy S and Paratkar, G. T. (2006). Biomonitoring of Trace Element Air Pollution Using Mosses. Aerosol and Air Quality Research, Vol. 6, No.3, pp. 247-258.

[16]. Giordano S, Adamo P, Spagnuolo V, Tretiach M, Bargagli R. (2013). Accumulation of airborne trace elements in mosses, lichens and synthetic materials exposed at urban monitoring stations: Towards a harmonisation of the moss-bag technique. Chemosphere. Volume 90, Issue 2, 292-299

[17]. De Nicola F, Spagnuolo V, Baldantoni D, Sessa L, Alfani A, Bargagli R, Monaci F, Terracciano S, Giordano S. (2013). Improved biomonitoring of airborne contaminants by combined use of holm oak leaves and epiphytic moss. Chemosphere. 92(9):1224-30. doi: 10.1016/j.chemosphere.2013.04.050.

[18]. Zarazúa-Ortega G, Poblano-Bata J, Tejeda-Vega S, Ávila-Pérez, P, Zepeda-Gómez C, OrtizOliveros H, and Macedo-Miranda G. (2013). Assessment of Spatial Variability of Heavy Metals in Metropolitan. The Scientific World Journal. http://dx.doi.org/10.1155/2013/426492.

[19]. Vukovic, G., Urosevic, M. A., Razumenic, I., Kuzmanoski, M., Pergal, M., Skrivanj, S., \& Popovic, A. (2014) - Air quality in urban parking garages (PM10, major and trace elements, PAHs): Instrumental measurements vs. active moss biomonitoring. Atmospheric Environment 85. $31-40$.

[20]. Vuković, G., Urošević, M. A., Pergal, M., Janković, M., Goryainova, Z., Tomašević, M., \& Popović, A. (2015) - Residential heating contribution to the level of air pollutants (PAHs, major, trace, and rare earth elements): a moss bag case study. Environ Sci Pollut Res. DOI $10.1007 / \mathrm{s} 11356-015-5096-0$.

[21]. Wilkins, K, Aherne J. (2015). Isothecium Myosuroides and Thuidium tamariscinum Mosses as Bioindicators of Nitrogen and Heavy Metal Deposition in Atlantic Oak Woodlands. Annali di Botanica. 5: 71 - 78. DOI: http://dx.doi.org/10.4462/annbotrm-13056

[22]. Capozzi F, Giordano S, Di Palma A, Spagnuolo V, De Nicola F, Adamo P (2016). Biomonitoring of atmospheric pollution by moss bags: Discriminating urban-rural structure in a fragmented landscape. Chemosphere. Volume 149, 211-218.

[23]. Suoranta T, Niemelä M, Poikolainen J, Piispanen J, Bokhari S. N. H, Meisel T and Perämäki $P$ (2016). Active biomonitoring of palladium, platinum, and rhodium emissions from road traffic using transplanted moss. Environ Sci Pollut Res (2016) 23: 16790. doi:10.1007/s11356-016-68801.

[24]. Fernández, J.A., Aboal, J.R., Carballeira, A., 2010. Testing differences in methods of preparing moss samples. Effect of washing on Pseudoscleropodium purum. Environ. Monit. Assess. 163, 669-684 
[25]. Adamo, P., Giordano, S., Sforza, A., Bargagli, R., 2011. Implementation of airborne trace element monitoring with devitalised transplants of Hypnum cupressiforme Hedw.: assessment of temporal trends and element contribution by vehicular traffic in Naples city. Environ. Pollut. 159, $1620-1628$.

[26]. Tretiach, M., Pittao, E., Crisafulli, P., Adamo, P., (2011). Influence of exposure sites on trace element enrichment in moss-bags and characterization of particles deposited on the biomonitor surface. Sci. Total Environ. 409, 822-830.

[27]. Ares, A., Fernández, J.A., Carballeira, A., Aboal, J.R., (2014). Towards the methodological optimization of the moss bag technique in terms of contaminants concentrations and replicability values. Atmos. Environ. 94, 496-507

[28]. Vukovic, G., Urosevic, M. A., Tomasevic, M., Samson, R., \& Popovic, A. (2015) Biomagnetic monitoring of urban air pollution using moss bags (Sphagnum girgensohnii). Ecological Indicators 52: 40-47.

[29]. Brown DH, Brown RM. Mineral cycling and lichens: the physiological basis. Lichenologist; 23:293-307.

[30] Castello M. (2007). Monitoring of airborne metal pollution by moss bags: a methodological study. Stud. Geobotanica, 15:91-103.

[31]. Aboal, J.R., Fernández, J.A., Boquete, T., Carballeira, A., (2010). Is it possible to estimate atmospheric deposition of heavy metals by analysis of terrestrial mosses? Sci. Total Environ. 408 (24), 6291-6297.

[32]. Aničić, M., Tasić, M., Frontasyeva,M.V., Tomašević,M., Rajšić, S., Strelkova, L.P., Popović, A., Steinnes, E., (2009). Active biomonitoring with wet and dry moss: a case study in an urban area. Environ. Chem. Lett. 7, 55-60.

[33]. Naszradi T, Badacsonyi A, Németh N, Tuba Z, Batič F. Zinc, lead and cadmium content in meadow plants and mosses along the M3 motorway (Hungary). J Atmos Chem 2004;49:593-603.

[34]. Boquete, M.T., Fernández, J.A., Aboal, J.R., Carballeira, A., 2011a. Analysis of temporal variability in the concentrations of some elements in the terrestrial moss Pseudoscleropodium purum. Environ. Exp. Bot. 72, 210-216.

[35]. Zechmeister HG, Dullinger S, Hohenwallner D, Riss A, Hanus-Illnar A, Scharf S. Pilot study on road traffic emissions (PAHs, heavy metals) measured by using mosses in a tunnel experiment in Vienna, Austria. Environ Sci Pollut Res; 13:398-405.

[35]. Temple PJ, McLaughlin DL, Linzon SN, Wills R. (1981). Moss bags as monitors of atmospheric deposition. J Air Pollut Control Assoc. 31:668-70. 
[36]. Clough WS. Deposition of particles on moss and grass surfaces. Atmos Environ 1975; 9:1113-9.

[37]. Mariet C, Gaudry A, Ayrault S, Moskura M, Denayer F, Bernard N. Heavy metal bioaccumulation by the bryophyte Scleropodium purum at three French sites under various influences: rural conditions, traffic, and industry. Environ Monit Assess. 174:107-18.

[38]. Basile A, Sorbo S, Aprile G, Conte B, Cobianchi RC. Comparison of the heavy metal bioaccumulation capacity of an epiphytic moss and an epiphytic lichen. Environ Pollut. 151:4017.

[39]. Fabure J, Meyer C, Denayer F, Gaudry A, Gilbert D, Bernard N. Accumulation capacities of particulate matter in an acrocarpous and a pleurocarpous moss exposed at three differently polluted sites (industrial, urban and rural). Water Air Soil Pollut 2010;212: 205-17.

[40]. Rivera M, Zechmeister H, Medina-Ramón M, Basagaña X, Foraster M, Bouso L, et al. Monitoring of heavy metal concentrations in home outdoor air using moss bags. Environ Pollut 2011; 159:954-62.

(C) 2017 by the authors. Licensee Preprints, Basel, Switzerland. This article is an open access article distributed under the terms and conditions of the Creative Commons by Attribution (CC-BY) license (http://creativecommons.org/licenses/by/4.0/). 